\title{
DAMPAK PANDEMI COVID-19 TERHADAP PERAN ORANG TUA DAN GURU DALAM MENINGKATKAN KUALITAS PEMBELAJARAN DARING ANAK USIA SEKOLAH DASAR
}

\author{
${ }^{1)}$ Puji Asmaul Chusna, STIT Al Muslihuun Tlogo Kanigoro Blitar, \\ email : hasmaul79@gmail.com \\ 2) Ana Dwi Muji Utami, Prodi PGMI, STIT Al Muslihuun Tlogo Kanigoro Blitar, \\ email : anadwiutami16@gmail.com
}

\begin{abstract}
This research aims to know the impact of the covid-19 pandemic on parents and teachers in improving the quality of online learning for elementary school age children, to find out the obstacles and supporters faced by teachers and parents in improving the quality of online learning for elementary school age children. This research is a qualitative descriptive study. The object of this study were teachers, students' parents, and students in the shade of MI ALHIKMAH Talun Blitar. Data collection techniques using observation and interviews. Semistructured interviews were conducted with a list of interview questions to be developed with related literature. The results of this study show the results that teachers always provide motivation, provide customised tasks with abilities and never squeeze in every task. Provide full guidance if needed by parents. This is also done by parents of students actively accompanying and guiding them in working on assignments. Trying to be comfortable but still disciplined to the maximum in accordance with the teacher's instructions. However, in addition to the less supportive facilities and infrastructure, they complained about the additional cost of buying an internet quota, the signals that were less supportive, children at home quickly got bored and misused when using an Android cellphone.
\end{abstract}

Keyword: covid impact, parents and teachers' role, online learning

\section{Pendahuluan}

Bermula dari Kota Wuhan, Tiongkok virus corona menyebar ke berbagai wilayah di dunia termasuk Indonesia. Pada Rabu 11 Maret 2020, Organisasi Kesehatan Dunia (WHO) telah menetapkan secara resmi coronavirus disease (Covid-19) sebagai pandemi. Pandemi coronavirus disease (Covid-19) yang menyebar di wilayah Indonesia berdampak pada berbagai bidang, salah satunya dalam bidang pendidikan. 
Dalam bidang pendidikan pemerintah mengeluarkan berbagai kebijakan sebagai upaya pencegahan meluasnya penularan coronavirus disease (Covid-19). Kebijakan pemerintah dalam bidang pendidikan berpengaruh terhadap seluruh jenjang pendidikan, salah satunya pada jenjang pendidikan Sekolah Dasar. Sistem kegiatan belajar mengajar yang biasanya dilakukan dengan tatap muka langsung antara guru dan peserta didik di kelas kini digantikan dengan sistem daring (dalam jaringan) guna menerapkan kebijakan social distance.

Dalam sistem pembelajaran secara daring (dalam jaringan) atau online, guru memberikan pengajaran atau tugas kepada peserta didik melalui aplikasi Whatsapp, Google Classroom, Email, dan aplikasi lain sebagainya guna mendukung terlaksananya kegiatan belajar mengajar sebagai ganti pembelajaran tatap muka.

Berdasarkan UU No. 20 tahun 2003 tentang Sistem Pendidikan Nasional pendidikan diartikan sebagai suatu usaha sadar dan terencana untuk mewujudkan suasana belajar dan proses pembelajaran agar peserta didik secara aktif mengembangkan potensi dirinya untuk memiliki kekuatan spiritual keagamaan, pengendalian diri, kepribadian, kecerdasan, akhlak mulia, serta keterampilan yang diperlukan dirinya, masyarakat, bangsa, dan negara. ${ }^{1}$

Walaupun sekolah diliburkan, kegiatan belajar-mengajar tetap dilaksanakan dari rumah. Guru tetap bertugas menjalankan perannya guna menyukseskan kegiatan belajar mengajar agar tujuan pendidikan tercapai. Dalam kaitannya peran guru dalam proses pembelajaran, Gage dan Berliner (dalam Suyono dan Hariyanto) melihat ada tiga fungsi utama guru dalam pembelajaran ${ }^{2}$, yaitu sebagai perencana (planner), pelaksana dan pengelola (organizer) dan penilai (evaluator).

Orang tua merupakan orang yang paling dekat dengan anak selama anak di rumah pada masa pandemi coronavirus disease (Covid-19) ini, peran orang tua sangat urgen, yakni menciptakan suasana dalam keluarga proses pendidikan yang berkelanjutan (continues progress) guna melahirkan generasi penerus (keturunan) yang cerdas dan berakhlak (berbudi pekerti yang baik), baik di mata orang tua maupun masyarakat.

Dalam keluarga anak dipersiapkan untuk menjalani tingkatan-tingkatan perkembangan sebagai bekal ketika memasuki dunia orang dewasa, bahasa, adat istiadat dan seluruh isi kebudayaan, seharusnya menjadi tugas yang dikerjakan keluarga dan masyarakat di dalam

1 Durotul Yatimah, Landasan Pendidikan, (Jakarta: CV Alumgadan Mandir, 2017), hal. 1.

2 Suyono dan Hariyanto, Belajar dan Pembelajaran Teori dan Konsep Dasar, (Bandung: PT Remaja Rosdakarya, 2014), Hal. 187. 
mempertahankan kehidupan oleh keluarga. ${ }^{3}$ Oleh sebab itu, orang tua sangat berperan dalam mendukung, meningkatkan dan menyukseskan kegiatan belajar anak di rumah.

Dari pemaparan di atas dapat disimpulkan bahwa peran orang tua dan guru sangat penting guna menyukseskan sistem pembelajaran secara daring (dalam jaringan) atau online. Adanya sikap saling mempercayai, saling membantu dalam membimbing anak dan berkomunikasi antara orang tua dan guru, akan membuat anak merasa memiliki kebebasan berkreativitas guna pengembangan potensi dirinya, sehingga bisa meningkatkan kreativitas dan mencapai keberhasilan dalam belajar.

Oleh karena itu dalam penelitian ini penulis merumuskan masalah sebagai berikut:

1) Bagaimana peran orang tua dan guru guna meningkatkan prestasi belajar anak usia sekolah dasar di masa pandemi coronavirus disease (Covid-19) dalam sistem pembelajaran secara daring (dalam jaringan) atau online?; 2) Apa saja faktor pendukung dan penghambat dalam pembelajaran daring di masa pandemi coronavirus disease (Covid-19) ?

Tujuan dari penelitian ini adalah untuk mengetahui dampak pandemi covid-19 terhadap orang tua dan guru dalam meningkatkan kualitas pembelajaran daring anak usia sekolah dasar, untuk mengetahui kendala dan pendukung yang dihadapi guru dan orang tua dalam meningkatkan kualitas pembelajaran daring anak usia sekolah dasar.

\section{Kajian Teori}

\section{Pandemi Covid-19 di Dunia Pendidikan}

Pada awal tahun 2020 dunia sedang dikejutkan dengan mewabahnya penyakit yang bernama virus corona. Virus ini disinyalir mulai terdeteksi Desember 2019 di kota Wuhan provinsi Hubei Tiongkok, dan menyebar dengan cepat di seluruh dunia. Sehingga pada tanggal 11 Maret 2020 WHO (World Health Organization) menetapkan wabah ini sebagai pandemi global.

Pandemi corona virus 2019-20 merupakan krisis kesehatan yang disebabkan oleh sindrom pernafasan akut yang parah coronavirus 2 (SARS-CoV-2). ${ }^{4}$ Pandemi corona ini memang sebuah ujian yang berat bagi seluruh bangsa, Akibat pandemi virus corona tidak hanya

\footnotetext{
${ }^{3}$ Selo Soemarjan, Sosiologii Suatu Pengantar, (Yogyakarta: Gajah Mada Press, 1962), hal. 127.

${ }^{4}$ Cyranoski D (Maret 2020). "Misteri memperdalam sumber hewan coronavirus". Alam . 579 (7797): 1819. Bibcode : 2020Natur.579 ... 18C. doi : 10.1038/d41586-020-00548-w. PMID 32127703 .diakses tanggal 19 April 2020, 01.00 WIB.
} 
pada sektor ekonomi yang lambat namun dalam dunia pendidikan juga merasakan dampaknya. Banyak negara yang memutuskan untuk menutup sekolah, terutama di Indonesia mulai dari taman pendidikan anak usai dini, sekolah dasar hingga perguruan tinggi dan universitas. Hal ini telah diakui oleh organisasi Pendidikan, Keilmuan, dan Kebudayaan Perserikatan BangsaBangsa (UNESCO), bahwa wabah virus corona telah berdampak terhadap sektor pendidikan. Hampir 300 juta siswa terganggu kegiatan sekolahnya di seluruh dunia dan terancam hak-hak pendidikan mereka di masa depan. ${ }^{5}$

Jika kondisi ini terus meningkat, maka dapat dipastikan dampaknya terhadap sektor pendidikan juga akan semakin meningkat. Dampak yang paling dikhawatirkan adalah efek jangka panjang. Sebab para siswa dan mahasiswa secara otomatis akan merasakan keterlambatan dalam proses pendidikan yang dijalaninya. Hal ini bisa mengakibatkan pada terhambatnya perkembangan kematangan mereka di masa yang akan datang.

Apalagi jika Covid-19 ini tidak segera berakhir. Dengan kebijakan penundaan sekolahsekolah di negara-negara yang terdampak virus tersebut secara otomatis dapat mengganggu hak setiap warganya untuk mendapatkan layanan pendidikan yang layak. Penutupan sekolah-sekolah dan kampus tersebut tentu dapat menghambat dan memperlambat capaian target yang sudah ditetapkan oleh pemerintah dan atau sekolah masing-masing.

Kondisi demikian akan mengganggu pencapaian kematangan siswa dalam meraih tujuan belajarnya, baik secara akademis maupun psikologis. Yang lebih mengkhawatirkan lagi adalah dampak psikologisnya. Siswa yang harus tertunda proses pembelajarannya akibat penutupan sekolah dan sangat memungkinkan akan mengalami trauma psikologis yang membuat mereka demotivasi dalam belajar.

Virus ini mudah menyebar dari satu orang ke orang lain. Efeknya pemerintah melarang berkumpul dalam jumlah yang banyak, tidak boleh dekat-dekat termasuk dengan siswa di sekolah. Walhasil, banyak kantor dan aktivitas lain diliburkan sampai waktu yang belum ditentukan. Dalam upaya mencegah penyebaran dan penularan Covid-19 diperlukan beberapa tindakan secara bersama-sama juga ketersediaan sarana dan prasarana lainnya. Seperti masker, hand sanitizer, fasilitas rumah sakit seperti ruang isolasi, tenaga medis, dan sebagainya.

\footnotetext{
${ }^{5}$ Bayumie sukri, Dampak Korona Terhadap Pendidikan, dalam "https://intens.news/corona-makin-eksis-duniapendidikan-bermetamorfosis/", diakses tanggal 19 April 202003.44 WIB.
} 
Pandemi corona ini memang sebuah ujian yang berat bagi seluruh bangsa, menguji kemampuan semua bangsa untuk dapat mengambil hikmah dengan terus berupaya dan berikhtiar mencari solusi pada setiap masalah yang ada. Kebijakan di bidang pendidikan pun diambil guna mencegah penyebaran dan penularan virus corona. Yaitu dengan diterbitkannya surat edaran tentang Belajar di Rumah. Di mana siswa mengerjakan tugas-tugas pembelajaran dari guru di rumah masing-masing secara online.

Pembelajaran dalam jaringan (daring) tersebut bahkan yang semula hanya 14 hari kini diperpanjang hingga bulan April 2020. Selain itu Ujian Nasional (UN) ditiadakan, dan pemantauan daring dilakukan oleh masing-masing sekolah terhadap siswanya. Menurut Menteri Pendidikan dan Kebudayaan Nadiem Makarim, sejak 2015 UN tidak lagi menjadi penentu kelulusan dan seleksi masuk sekolah. Maka dengan berat hati menyampaikan pada tahun ini karena kasus darurat Covid-19, pihaknya tidak bisa melakukan pemetaan secara komperehensif.

\section{Pembelajaran Daring Masa Darurat}

Sebagai upaya mengantisipasi penyebaran Covid-19, Pemerintah Pusat diikuti Pemerintah Daerah meliburkan sekolah. Sebagai solusinya pembelajaran di sekolah digantikan dengan pembelajaran dalam jaringan (daring) atau akrab disebut online.

Di dalam bukunya "The One World Schoolhouse", Salman Khan mengatakan, "Pendidikan tidak terjadi di dalam ruang antara mulut guru dan telinga murid. Pendidikan terjadi di ruang di dalam otak masing-masing." Hal ini sejalan dengan teori pembelajaran konstruktivisme bahwa ilmu pengetahuan itu dibangun oleh murid melalui proses belajar, bukan dipindahkan dari guru ke murid. Mengingat hal tersebut tidak alasan untuk meragukan bahkan menolak pembelajaran daring. ${ }^{6}$

Secara umum, pembelajaran daring bertujuan memberikan layanan pembelajaran bermutu secara dalam jaringan (daring) yang bersifat masif dan terbuka untuk menjangkau audiens yang lebih banyak dan lebih luas. Pembelajaran moda daring merupakan pemanfaatan jaringan internet dalam proses pembelajaran. Pendekatan pembelajaran model daring memiliki karakteristik sebagai berikut: $^{7}$

\footnotetext{
${ }^{6}$ Yusuf Bilfaqih dan M. Nur Qomarudin, Esensi Pengembangan Pembelajaran Daring (Yogyakarta: Deepublish, 2015), hal. 3.

${ }^{7}$ Mhd. Isman, Pembelajaran Moda Dalam Jaringan (Moda Daring), Universitas Muhammadiyah Sumatera Utara, 2016.
} 
a) Menuntut pembelajar untuk membangun dan menciptakan pengetahuan secara mandiri (constructivism).

b) Pembelajar akan berkolaborasi dengan pembelajar lain dalam membangun pengetahuannya dan memecahkan masalah secara bersama-sama (social constructivism).

c) Membentuk suatu komunitas pembelajar (community of learners) yang inklusif.

d) Memanfaatkan media laman (website) yang bisa diakses melalui internet, pembelajaran berbasis komputer, kelas virtual, dan atau kelas digital.

e) Interaktivitas, kemandirian, aksesibilitas, dan pengayaan (Ditjen GTK 2016:6).

Untuk menghasilkan pembelajaran daring yang baik dan bermutu ada beberapa prinsip desain utama yang harus dipenuhi, ${ }^{8}$ yaitu:

a) Identifikasi capaian pembelajaran bagi mahasiswa atau peserta pendidikan dan pelatihan, mencakup aspek pengetahuan, keterampilan dan sikap.

b) Menjamin strategi asesmen selaras dengan capaian pembelajaran.

c) Menyusun aktivitas dan tugas pembelajaran secara progresif agar peserta pendidikan dapat mematok target pengetahuan, keterampilan dan sikap yang dibangun dalam proses belajarnya.

1) Menyajikan materi yang mendukung belajar aktif.

2) Dalam durasi pembelajaran, pengetahuan dibangun mulai dari yang mendasar lalu meningkat menuju keterampilan pada tingkat yang lebih tinggi seperti aplikasi, integrasi dan analisis.

d) Menjamin keseimbangan antara kehadiran pemberi materi, interaksi sosial, tantangan atau beban kognitif.

Dalam keadaan normal belajar di sekolah maupun di rumah memiliki tujuan pembelajaran yang sama dan relative efektif. Yang membedakan adalah sarana pendukung dan fasilatas yang dimiliki. Dalam keadaan yang belum menentu, dihantui dengan wabah yang mematikan seperti pandemi Covid-19 sesuai dengan anjuran dan kebijakan pemerintah, maka belajar dengan jarak jauh menjadi solusi alternatif pembelajaran sementara demi keselamatan bersama dan mencegah penyebaran virus.

\footnotetext{
${ }^{8}$ Yusuf Bilfaqih dan M. Nur Qomarudin, Esensi Pengembangan Pembelajaran ..., hal. 6.
} 


\section{Pembelajaran Anak Usia Sekolah Dasar}

Pembelajaran pada anak usia sekolah dasar, hendaknya disesuaikan dengan karakteristik yang dimiliki dan kebutuhan yang diperlukan oleh usia anak sekolah dasar. Dengan harapan dapat mengembangkan potensi serta menumbuhkan semangat saat proses belajar berlangsung.

Belajar adalah proses yang dilakukan manusia untuk mendapatkan aneka ragam competencies (kemampuan), skill (keterampilan), dan attitudes (sikap) yang diperoleh secara bertahap dan berkelanjutan mulai dari masa bayi sampai masa tua sepanjang hayat. ${ }^{9}$ Belajar dapat dilakukan dengan cara membaca, mendengar, melihat dan merasa. Semua aktifitas ini dilakukan manusia dalam rangka belajar, baik secara formal, informal, maupun non formal. Khusus untuk pendidikan formal, yaitu pendidikan yang dilaksanakan di lembaga sekolah, maka semua aktivitas belajar tersebut pada prinsipnya untuk satu tujuan, pencapaian prestasi belajar, baik dalam bidang kognitif, afektif, maupun psikomotor.

Pada masa usia sekolah dasar, sesuai dengan perkembangnnya mereka memiliki karakteristik yang unik senang bermain, bergerak, bermain dengan kelompok, senang melakukan secara langsung, masih cengeng sulit memahami perkataan orang lain, senang diperhatikan dan senang meniru.

Beberapa teori tersebut di antaranya yaitu teori kognitif, teori psikososial, teori moral, teori perkembangan fisik dan motorik. Konsep-konsep di dalamnya akan dibahas lebih lanjut sebagai berikut: ${ }^{10}$

a) Perkembangan Kognitif Anak Usia SD

Teori perkembangan kognitif yang dikemukakan oleh Piaget menyatakan bahwa anak usia SD pada umumnya berada pada tahap operasional konkret untuk anak dengan rentang usia 7 sampai 11 tahun. Pada tahap ini,anak sudah dapat melakukan penalaran secara logis untuk hal-hal yang bersifat konkret, sedangkan untuk hal-hal yang bersifat abstrak masih belum mampu.

b) Perkembangan Psikososial Anak Usia SD

Perkembangan psikososial dalam teori Erikson memberikan pandangan bahwa manusia dalam perkembangan psikososialnya mengalami perubahan-perubahan sepanjang hidupnya.

\footnotetext{
${ }^{9}$ Udin S. Winataputra, Teori Belajar dan Pembelajaran Modul, Universitas Terbuka, 2014.

${ }^{10}$ Rima Trianingsih, Pengantar Praktik Mendidik Anak Usia Sekolah Dasar Article, IAI Ibrahimy Genteng Banyuwang, Vol. 3 No. 2, 2016, hal. 199-203.
} 
Pandangan Erikson terhadap perkembangan psikososial anak usia SD menekankan pada proses-proses sadar yang dialami anak ketika berinteraksi sosial.

c) Perkembangan Moral Anak Usia SD

Tahapan-tahapan perkembangan moral Piaget membagi tahap perkembangan moral menjadi dua, yaitu moralitas heteronom dan moralitas otonom. Moralitas heteronom (usia 4 sampai 7 tahun) yaitu tahap di mana anak memahami keadilan dan peraturan sebagai sesuatu yang berada di luar kendali manusia sehingga tidak dapat diubah atau bersifat tetap sehingga dalam menilai dari suatu tindakan hanya melihat pada konsekuensinya. Moralitas otonom (usia 10 tahun ke atas) yaitu tahap di mana anak sadar bahwa peraturan dibuat oleh manusia sehingga dalam menilai suatu tindakan harus mempertimbangkan niat pelaku dan konsekuensinya. Anak usia SD antara 7 sampai 10 tahun berada pada masa transisi moralitas heteronom ke moralitas otonom sehingga pada moralitas anak akan ditemukan kedua karakteristik perilaku pada kedua tahap tersebut (Santrock, 2003: 439).

d) Perkembangan Fisik dan Motorik Anak Usia SD

Perkembangan fisik dan motorik anak adalah sesuatu yang tidak terpisahkan. Fisik seseorang akan mempengaruhi gerak motoriknya. Anak SD umumnya berada pada fase tenang $\left(\right.$ stabil $^{11}$, di mana perkembangan fisik pada masa ini terbilang lambat namun konsisten. Ciriciri perkembangan fisik yang mendasar pada anak SD usia 7 hingga usia 9 tahun, anak perempuan lazimnya lebih pendek dan ringan daripada anak laki-laki. Pada usia 9 sampai 10 tahun, anak perempuan lazimnya memiliki tinggi dan berat badan yang sama dengan anak laki-laki. Pada usia sekitar 11 tahun anak perempuan lebih tinggi dan berat dibandingkan anak laki-laki. Akan tetapi, Perkembangan motorik penting untuk dikembangkan melalui proses pembelajaran.

Dalam perjalanan pembelajaran, tidaklah selulu mulus dan lancar sesuai dengan perencanaan. Ngalim Purwanto menyatakan bahwa, ada faktor-faktor yang mempengaruhi belajar anak, yaitu faktor internal (faktor dari dalam diri anak), yakni keadaan jasmani dan rohani anak, dan faktor eksternal (faktor dari luar diri anak), yakni kondisi lingkungn di sekitar anak. ${ }^{12}$

Karena secara individu, anak terdiri dari dua substansi yaitu fisiologis (fisik) dan psikologis (kejiwaan). Kemudian secara sosial, anak hidup di lingkungannya, baik keluarga,

\footnotetext{
${ }^{11}$ Wiji Hidayati dan Sri Purnami, Psikologi Perkembanga, (Yogyakarta: Teras, 2008), hal. 130.

${ }^{12}$ Ngalim Purwanto, Psikologi Pendidikan, (Bandung: Remaja Rosdakarya, 1991), hal. 10.
} 
masyarakat, dan sekolah. Kesemua faktor ini, saling berkaitan dan saling berpengaruh satu sama lainnya, terutama dalam peningkatan pembelajaran anak.

\section{Peran Orang Tua dan Guru dalam Pembelajaran}

Peran orang tua di rumah dan guru di sekolah sangat penting bagi pendidikan anak. Komunikasi yang baik antara orang tua dan guru merupakan suatu keharusan agar tercapai kesinergian antara keduanya. Komunikasi tersebut bisa berlangsung dalam satu arah ataupun dua arah. Komunikasi satu arah terjadi saat guru memberikan informasi kepada orang tua tentang peristiwa, kegiatan, atau kemajuan yang dicapai anak. Sedangkan komunikasi dua arah terjadi jika ada dialog interaktif antara guru dan orang tua. Komunikasi yang baik akan menumbuhkan sikap saling percaya antara orang tua dan guru. Adanya sikap saling mempercayai, saling membantu dalam membimbing anak dan berkomunikasi antara orang tua dan guru, akan membuat anak merasa memiliki kebebasan berkreativitas guna pengembangan potensi dirinya, sehingga bisa meningkatkan kreativitas dan mencapai keberhasilan dalam belajar.

\section{a. Peran Guru}

Peran merupakan gaya atau tingkah laku yang dilakukan untuk memenuhi tugas. Seorang guru merupakan faktor penentu yang sangat dominan dalam pendidikan pada umumnya, karena guru memegang peranan yang sangat penting dalam suatu proses pembelajaran. Selain dari pada itu, guru juga memiliki peranan yang sangat banyak yaitu meliputi, pengajar, pemimpin kelas, pembimbing, pengatur lingkungan belajar, perencana pembeajaran, supervisor, motivator, dan sebagai evaluator. ${ }^{13}$ dalam referensi lain Gage dan Berliner (dalam Suyono dan Hariyanto) melihat ada tiga fungsi utama guru dalam pembelajaran, yaitu sebagai perencana (planner), pelaksana dan pengelola (organizer) dan penilai (evaluator). ${ }^{14}$ Dari gambaran kelas masa depan, Gary Flewelling dan William Higginson (2003) menggambarkan peran guru sebagai berikut: ${ }^{15}$

1) Memberikan stimulasi kepada siswa dengan menyedikan tugas-tugas pembelajaran yang kaya (rich learning tasks) dan terancang dengan baik untuk meningkatkan perkembangan intelektual, emosional, spiritual, dan sosial.

\footnotetext{
${ }^{13}$ Rusman, Model-Model Pembelajaran; Mengembangakan Profesionalisme Guru, (Jakarta: PT Raja Grapindo Persada, 2011), hal. 58.

${ }^{14}$ Suyono dan Hariyanto, Belajar dan Pembelajaran Teori dan Konsep Dasar, (Bandung: PT Remaja Rosdakarya, 2014), hal. 187.

${ }^{15}$ Gary Flewelling and William Higginson. Teaching with Rich Learning Tasks. Adelaide: The Australian Association of Mathematic Teacher.(tp:ttp. 2003 ), hal. 189.
} 
2) Berinteraksi dengan siswa untuk mendorong keberanian, mengilhami, menantang, berdiskusi, berbagi, menjelaskan, menegaskan, merefleksi, menilai dan merayakan perkembangan, pertumbuhan dan keberhasilan.

3) Menunjukkan manfaat yang diperoleh dari mempelajari suatu pokok bahasan.

4) Berperan sebagai seseorang yang membantu, seseorang yang mengerahkan dan memberi penegasan, seseorang yang memberi jiwa dan mengilhami siswa dengan cara membangkitkan rasa ingin tahu, rasa antusias, gairah dari seorang pembelajar yang berani mengambil resiko (risk taking learning), dengan demikian guru berperan sebagai pemberi informasi (informer), fasilitator, dan seorang artis.

Dari uraian diatas terlihat begitu penting peran seorang guru dalam dunia pendidikan. Menjadi salah satu komponen penting dalam mencapai tujuan pembelajaran. Karena gurulah yang selalu berinteraksi dengan peserta didik melalui tatap muka di sebuah lembaga. Menguasai kondisi lapangan sehingga berusaha mewujudkan pembelajaran yang menyenangkan dan efektif sesuai dengan kemampuan peserta didik.

\section{b. Peran Orang Tua}

Orang tua merupakan orang yang paling dekat dengan anak selama anak di rumah. Dari semua faktor eksternal, maka orangtualah yang paling berperan dalam menentukan prestasi belajar anak. Orang tua merupakan sosok pertama dan utama dalam pendidikan anak. Meskipun anak telah dititipkan ke sekolah, tetapi orang tua tetap berperan terhadap prestasi belajar anak.

Orang tua memiliki peran yang sangat penting dalam keluarga. Orang tua merupakan guru pertama dan utama bagi anak-anaknya karena dari orang tua lah anak mendapatkan bimbingan dan kasih sayang yang pertama kalinya. Oleh karena itu, orangtua memegang peranan penting untuk mengorganisir kondisi belajar di keluarga, untuk menunjang prestasi belajar anak. Berikut ini peranan orangtua dalam mengoptimalkan prestasi belajar anak: ${ }^{16}$

1) Orang tua sebagai pendidik (educator), artinya dalam proses pendidikan anak dapat memainkan peran dalam pembentukan pribadi dan moral, bahkan meletakkan dasar-dasar dalam kecakapan hidup.

2) Orang tua sebagai guru, artinya bahwa orang tua dalam kehidupan sehari-hari dapat memainkan peran untuk melakukan kegiatan belajar, apakah itu kegiatan membaca, menulis,

\footnotetext{
${ }^{16}$ Rochmat Wahab, Peranan Orangtua dan Pendidik dalam Mengoptimalkan Potensi Anak Berbakatak Ademik, Dibahas dalam SEMINAR KEBERBAKATAN yang diselenggarakan oleh Dewan Eksekutif Mahasiswa Psikologi Universitas Diponegoro, Semarang pada 28 Mei 2005 di Semarang.
} 
maupun berhitung, sehingga anak-anak memiliki kesiapan untuk melakukan aktivitas belajar sebagaimana yang dikehendaki di sekolah.

3) Orang tua sebagai motivator, artinya bahwa orang tua dapat memotivasi anak dan mendorongnya baik langsung maupun tidak langsung, sehingga membuat anak-anak itu menyukai kegiatan belajar dan bekerja.

4) Orang tua sebagai supporter, artinya bahwa orang tua seharusnya mampu memberikan dukungan baik moril maupun materil yang sangat diperlukan anak untuk melakukan kegiatan belajar baik di rumah maupun kepentingannya di sekolah. Dukungan yang diberikan hendaknya didasarkan pada prinsip-prinsip pedagogis, sehingga benar-benar dukungannnya lebih bermakna bagi pertumbuhan dan perkembangan anak.

5) Orang tua sebagai fasilitator, artinya bahwa orang tua seharusnya mampu menyisihkan waktu, tenaga, dan kemampuannya untuk menfasilitasi segala kegiatan anak dalam proses pertumbuhan dan perkembangannya. Orang tua dapat menciptkan lingkungan yang kondusif bagi terciptanya kegiatan belajar dan bermain bagi anak di rumah, sehingga memungkinkan semua kebutuhan anak untuk tumbuh dan berkembang dapat dicapai dengan mudah.

6) Orang tua sebagai model, artinya bahwa orang tua seharusnya menjadi contoh dan teladan di rumah dalam berbagai aspek kecakapan dan perilaku hidupnya, sehingga anak-anak dapat mengikuti yang baik-baik di rumah, sebelum anak-anak memasuki kehidupan di tengahtengah masyarakat. Misalnya tutur kata, kebiasaan membaca, berdialog atau berdiskusi setiap menghadapi persoalan dengan cara yang sedemokratis mungkin dan tidak dengan sikap otoriter, respek antara sesama, dan sebagainya.

Pendidikan anak bukan hanya kewajiban guru, namun partisipasi orang tua sangatlah penting. Tidak hanya menemani belajar di rumah namun juga menjadi teladan bagi putraputrinya. Semua kebiasaan baik dan buruk bermula dari pembiasaan yang dilakukan orang tua terhadap anaknya. Oleh karenanya pola asuh sangatlah menentukan dalam pendidikan anak untuk mencapai kesuksesan.

\section{Metodologi}

Studi yang dilakukan dalam penelitian ini adalah eksplorasi deskriptif dengan analisis kualitatif. ${ }^{17}$ Peneliti secara langsung turun sendiri ke lapangan, aktif mengamati, mencatat dan

\footnotetext{
${ }^{17}$ Sugiyono, Metode Penelitian Kombinasi. Bandung: Alfabeta, 2011), hal. 7.
} 
bertanya sebagai kunci dalam instrumen penelitian yang diperoleh dari lapangan. Penelitian ini digunakan untuk mendapatkan informasi kendala dan akibat dari pandemi Covid-19 terhadap proses pembelajaran secara daring di sekolah dasar.

Perolehan data dilakukan secara alamiah naturalistic, yakni berkembang dengan apa adanya tanpa manipulasi oleh peneliti. Karena peneliti dalam penelitain ini bersifat netral, tidak mempengaruhi dinamika pada obyek tersebut.

Objek dalam pelitian ini adalah MI AL-HIKMAH yang berada di desa Jabung. Waktu penelitian dilaksanakan mulai bulan Maret hingga April 2020. Fokus pada penelitian ini adalah guru dan orang tua MI AL-Hikmah tahun ajaran 2019/2020. Dengan teknik pengumpulan data melalui observasi, wawancara mendalam, pencarian literature, serta dokumentasi.

Dengan demikian riset ini hanya difokuskan pada beberapa responden yang mewakili guru dan orang tua. Karena dalam pengambilan sampel bukan masalah representative pandangan, tetapi lebih merupakan kekayaan informasi. ${ }^{18}$ Sehingga penelitian ini merupakan studi kasus eksplorasi dengan sampel yang dipilih mengunakan metode purposive sampling. Metode ini digunakan untuk mencapai tujuan penelitian tertentu. ${ }^{19}$

Dalam penelitian ini responden diwawancarai hingga saturasi data tercapai dan tidak ditemukan lagi informasi yang baru. Pelaksanaan wawancara dilakukan di rumah responden dengan tetap mengatur jarak sesuai dengan peraturan yang telah ditetapkan karena dalam pandemi yang berbahaya, akan tetapi tidak lupa selalu membuat responden nyaman dan rileks agar informasi yang didapat sesuai dengan tujuan penelitian.

Wawancara yang dilakukan atas izin dari responden, informasi yang didapatkan dicatat secara umum yang kemudian ditrasnkipkan lebih verbal. Kemudian dilanjutkan untuk melakukakan analisis dan interprestasi data yang menjadi bagian utama dalam penelitian kualitatif. $^{20}$

Tabel 1. Profil Responden

\begin{tabular}{|l|l|l|l|}
\hline Inisial & Jemis kelamin & Usia & Pendidikan \\
\hline Q1 & Laki-laki & 45 & S1 \\
\hline
\end{tabular}

\footnotetext{
${ }^{18}$ Anonim, Pengambilan sampel. Dalam "https://id.wikipedia.org/wiki/Sampel_(statistika)", diakses tanggal 19 April 2020 pukul 00.24 WIB.

${ }^{19}$ Portal statistic, Pengambilan Sampel Purposive, dalam "http://www.portal-statistik.com/2014/02/teknikpengambilan-sampel-dengan-metode.html", diakses tanggal 19 April 2020 pukul 00.30 WIB.

${ }^{20}$ Hadari Nawawi, Metode Penelitian Bidang Sosial,(Yogyakarta: Gajah Mada Universitas Press, 2011), hal. 112.
} 


\begin{tabular}{|l|l|l|l|}
\hline Q2 & Perempuan & 40 & S1 \\
\hline Q3 & Perempuan & 42 & S1 \\
\hline Q4 & Perempuan & 37 & S1 \\
\hline Q5 & Perempuan & 35 & S1 \\
\hline Q6 & Perempuan & 32 & S1 \\
\hline Q7 & Perempuan & 34 & SMA \\
\hline
\end{tabular}

Untuk menjaga kerahasiaan maka responden diberi inisial Q1,Q2,Q3,Q4,Q5,Q6 dan Q7. sementara informasi lain hanya dijadikan data yang bersifat sekunder dan pelengkap semata. Pemilihan objek ini berdasarkan pertimbangan persebaran domisili yang heterogen tempat tinggal guru dan orang tua.

\section{Hasil}

Tujuan dalam penelitian ini adalah untuk mengetahui dampak Pandemi Covid-19 terhadap peran guru dan orang tua dalam meningkatkan kualitas Pembelajaran Daring Anak Usia Sekolah Dasar. Semua tanggapan responden adalah kutipan asli, dan telah dikutip sesuai dengan yang dinyatakan responden.

Seorang dari responden (Q1) menyatkan bahwa :

"Selalu mengontrol kegiatan melalui orang tua siswa secara langsung, memberikan tugas sesuai dengan kemampuan dan perkembangan anak namun tetap diusahakan sesuai dengan tujuan pembelajaran yang diharapkan"

Sedangkan dari (Q2) memberikan pernyataan :

"Guru harus kreatif untuk mengemas pembelajaran daring dengan menyesuaikan materi, metode pembelajaran dan pemakaian yang pas untuk keadaan siswa" responden $(\mathrm{Q} 3)$ menambahkan :

"Sebagai guru tidak boleh memberikan tugas yang dirasa memberatkan siswa, tidak berani menekan, karena khawatir akan menurunkan imun, yang penting mereka setiap hari diberikan tugas dan bimbingan agar mereka tetap belajar" sedangkan pernyataan dari yang lain menyatakan bahwa:

"Selalu mendampingi anak, santai tapi tetap serius, kadang saat dia bermain tak biarkan, nanti kiranya sudah lama bermian baru diajak belajar, Cuma gitu mbak... tapi saya berusaha membuat anak bahagia, kasihan kalau terlalu serius, sudah gak pernah 
refresing malah ditekan"

"Dia senang dengan camilan semacam snack, atau jajanan, jadi saya juga mengusahakan memberikan jajanan biar dia juga semangat dalam mengerjakan tugastugasnya" (Q4)

Pernyataan yang berbeda juga disampaiakn oleh (Q5)

"Saya temani untuk diajari membaca materi sampai habis mbak... Tak usahakan tepat waktu dan tugas selesai dengan baik, saya damping full khawatir dia menyalahgunakan $H P^{\prime}$

responden (Q6) menyampaikan:

"Saya bingung mbak.... Anakku ngertine sekolah libur... Tugas-tugas jarang terselesaikan dengan baik, sudah dinasehati, sudah disemangati akan tetapi fikirannya masih bermain, belum bisa fokus dengan baik" Sedangkan responden terakhir menyatakan (Q7):

"Sabar menemani anak mbak... Membuat suasana nyaman belajar, berusaha memberikan waktu dan mendampinginya sampai tugas-tugas sekolah selesai, jika ada materi yang sulit langsung nelfon atau wa kepad guru yang bersangkutan" Responden lain juga menyatakan:

"wali siswa sering mengeluhkan terbentur pada kuota, sehingga tugas tidak terselesaikan dengan tepat, atau terkadang HPnya dibawa orangatua siswa manjing jadi mengerjakan tugasnya sore/malam"(Q1).

"HP saya lemoot mbak.... Anak sayakan 3 meskipun yang sekolah masih 2 semua memiliki tugas masing-masing yang harus dilaporkan, jadi ya bergantian, terus harus ekstra sabar mbak... Terkadang harus nunggu bapak.e anak-anak dulu biar biasa dibantu momong yang anak ke 3, jadi biar saya bisa fokus menemani anak 1 dan 2. Kalu gak gitu kadang anak-anak mengerjakannya ngawur yang penting selesai... Tapi kalau saya sudah capek (dengan aktifitas rumah tangga yng lain) )membuat kewalahan dengan polah tingkah lakunya mbak... Anak-anak mudah bosen mbak.. Gak betah kalua full duduk manis mengerjakan tugas" (Q7).

"Saya lama-lama kasihan mbak... Anak sering mandengi HP, salah dalam memanfaatkan HP buat bermain game" (Q4).

"Saya dengan ekonomi yang pas-pasan harus meluangkan beli kuota internet... Kadang 
pas sinyalnya bagus lancar kalau pas gak bagus ya tugas tidak terselesaikan dengan tepat waktu" (Q5).

Responden (Q3) menambahkan :

"Ternyata tidak semua orang tua siswa memiliki HP android yang memadai, ada juga yang belum faham bagaimana mengerjakan atau membantu anaknya cara menyelesaikan tugas, sehingga dikatakan dari 100\% hanya $90 \%$ yang mengerjakan tugas dari guru".(Q1)

"Yang terpenting jaringan internet, tapi mereka banyak yang mengeluhkan internet susah, mungkin bisa jadi belum mampu membeli kuota atau memang susah sinyal dan memang ada yang tidak punya HP"(Q2).

"Kami selalu berusaha membimbing dan menyiapkan waktu kapanpun sesuai yang dibutuhkan wali murid selama dalam batas wajar untuk menunjang selesainya tugas yang kami berikan" $(Q 1)$

"Dengan memberikan tugas yang bervariasi tentunya sesuai dengan tujuan pembelajaran tiap indikator, harapan kami mereka tidak mudah bosen, tetap dapat bermain namun tugas belajar selesai dengan tujuan pembelajaran, jadi gak hanya lewat googleform, tapi bisa lewat video, mengirim hastakarya, mengirim foto, dll”. (Q3)

\section{Dampak Peran Guru}

Guru tetap melaksanakan kegiatan belajar-mengajar meskipun peserta didik berada di rumah, tanpa tatap muka diperlukan adaptasi untuk pembelajaran jarak jauh dengan media internet. Penyesuaian tersebut tentu akan berdampak pada hasil belajar yang kurang maksimal. Dalam sistem pembelajaran daring peran guru menjadi terbatas, guru lebih ke pengamat. Dalam penyampaian materipun guru tak mampu secara langsung dan mendetail karena terbatas ruang dan waktu. Hal tersebut berdampak pada kurangnya pemahaman siswa terhadap materi yang disampaikan guru.

Inovasi pembelajaran merupakan solusi yang perlu didesain dan dilaksanakan oleh guru dengan memaksimalkan media yang ada seperti media daring (online). Guru dapat melakukan pembelajaran menggunakan metode E-Learning yaitu pembelajaran memanfaatkan teknologi informasi dan komunikasi. Sistem pembelajaran dilaksanakan melalui perangkat komputer (PC) atau laptop yang terhubung dengan koneksi jaringan internet, dan Handphone. Guru dapat 
melakukan pembelajaran bersama diwaktu yang sama menggunakan grup di media sosial seperti Whatsapp (WA), google form sehingga dapat memastikan siswa tetap belajar.

Dalam kondisi pandemi Covid-19 guru lebih selektif dalam memberikan tugas kepada setiap siswanya, selain agar daya tahan tubuh tetap terjaga agar terhindar dari penyebaran virus, guru berusaha untuk memberikan tugas yang variatif. Hal ini bertujuan agar dalam proses pembelajaran jarak jauh siswa tidak mudah bosan dan tetap semangat dalam belajar. Selain itu guru berusaha siap setiap waktu jika menerima dan segera memberikan solusi kepada orang tua siswa. Seperti menanyakan dalam kesulitan materi meskipun di luar waktu. Sehingga membuat jam kerja menjadi tidak terbatas.

Sebagai seorang pendidik, guru dapat membuat media pembelajaran yang baik dan menarik agar materi pembelajaran dapat tersampaikan kepada peserta didik serta tujuan pembelajaran dapat tercapai. Perlu diingat bahwa belajar tidak melulu tentang membaca buku. Guru dapat memberikan tugas kepada anak berupa membuat suatu karya dalam pelajaran prakarya/seni budaya untuk mengembangkan kekreativitasan anak. Selain itu, guru dapat memberikan tugas berupa observasi di dalam rumah, mengamati kegiatan di rumah, dan membantu pekerjaan orang tua guna menumbuhkan pendidikan karakter. Buat siswa nyaman ketika belajar di rumah. Usahakan jangan memberatkan anak, dan jangan sampai membuat anak bosan dan tidak betah di rumah dengan setumpuk tugas.

Pembelajaran dalam jaringan juga terdapat kemudahan bagi guru dalam membuat soal. Tidak memerlukan waktu lama, serta lebih efektif dalam tenaga. Karena menggunakan google form guru dapat lebih cepat mengetahui nilai dari peserta didik tanpa melakukan koreksi yang detail. Namun jika tugas harus mengumpulkan file atau video akan memakan waktu yang lama dalam mengoreksi, HP terkadang juga menjadi lambat karena siswa lumayan banyak, setiap hari, dengan pelajaran yang berbeda, antar kelas, sehingga memori menjadi penuh dan beberpa aplikasi tidak berjalan dengan normal.

Selain itu, guru harus mengeluarkan biaya tambahan untuk membeli kuota internet karena tidak semua guru di rumah memasang wifi. Guru juga kesulitan komunikasi dengan teman sejawat untuk mendiskusikan pembelajaran. Tidak hanya pembelajaran, guru juga jenuh, jiwa sosial menurun jika pandemi belum berakhir, karena terbiasa komunikasi dengan teman sejawat untuk menghilangkan penat dan meningkatkan semangat yang berbeda. 


\section{Peran Orang Tua}

Pada masa pandemi coronavirus disease (Covid-19) ini, anak menghabiskan lebih banyak waktu di rumah sehingga lebih dekat dengan keluarga terutama orang tua. Oleh karena itu, sangat urgen bagi orang tua menjalankan perananya mengorganisir kondisi belajar di keluarga, untuk menunjang prestasi belajar anak. Sama halnya dengan guru, para orang tua harus menambah membeli kuota internet dan pulsa demi memperlancar kegiatan belajar anak di rumah.

Di sini peran orang tua lebih aktif sebagai pendamping, pengawas, dan pengontrol kegiatan belajar anak di rumah. Pendampingan orang tua sangat dibutuhkan terutama dalam penyampain materi, menyelesaikan tugas dan membantu dalam setiap kesulitan. Tak jarang juga banyak orang tua yang mengeluhkan tidak faham dengan materi anak sekolah zaman sekarang, materi lebih sulit dari zamannya dulu mereka sekolah.

Selain itu pengawasan dan pengontrolan orang tua terhadap anak dalam penggunaan handphone sangat penting, jangan sampai anak menyalahgunakan. Orang tua juga dapat mendukung himbauan pemerintah untuk penerapan pola hidup bersih dan sehat, mematuhi aturan pemerintah untuk mencegah penyebaran penularan virus corona (Covid-19). Hal ini sangat penting guna menumbuhkan pendidikan karakter dalam pendidikan selama anak belajar di rumah. Motivasi dari orang tua juga penting agar anak semangat belajar di rumah.

Orang tua juga mengeluhkan fasilitas yang kurang memadai, tidak semua orang tua memiliki laptop dan HP Android yang bagus. Yang masih digunakan dalam seluruh anggota rumah, terutama dibawa bapak bekerja, sehingga anak harus menunggu orang tuanya pulang baru bisa mengerjakan tugas dan melaporkannya kepada guru.

Jika dalam 1 rumah hanya 1 yang sekolah makan akan lebih ringan, tapi ada beberapa orang tua yang memiliki anak 2-3 yang sekolah, jadi perlu tambahan waktu, kesabaran dan ketenangan dalam mengahadapi setiap keluhan anaknya dalam menemani belajar. Sesuai dengan perkembangnnya mereka tidak dapat berdiam diri, mudah bosan, tidak fokus, dan terkadang menyalah gunakan hp untuk bermain game.

Untuk menghilangkan bosan dan menjaga tetap semangat dalam belajar ada beberapa orang tua menyiapkan camilan-camilan yang mereka sukai, dengan demikian orang tua harus menambah uang jajan, padahal tidak semua orang tua dalam keadaan ekonomi yang stabil. 
Tidak semua orang tua dapat menemani anaknya, beberapa orang tua dengan tuntutan pekerjaanya menjadi salah satu faktor kurang maksimalnya tujuan pembelajaran. Namun, ada hikmah dibalik pandemi covid-19 bagi orang tua, mereka menyadari betapa besar perjuangan seorang guru di sekolah dalam membimbing putra-putrinya, orang tua mengalami ternyata tidak mudah dalam menemani belajar, belajar anak itu tak cukup hanya di sekolah. Orang tua juga harus berperan, sekaligus saatnya penghargaan peran dan pengabdian para guru.

\section{Kualitas Pembelajaran Daring Anak Usia Sekolah Dasar}

Kurang lebih 6 minggu, sejak Mendikbud mengeluarkan Surat Edaran Nomor 36962/MPK.A/HK/2020 agar seluruh kegiatan belajar mengajar baik di sekolah maupun kampus perguruan tinggi menggunakan metoda daring (dalam jaringan) alias online sebagai upaya pencegahan terhadap perkembangan dan penyebaran coronavirus disease (Covid-19). Banyak sekali kisah menarik, lucu, maupun sedih yang terjadi dalam proses belajar dengan metode ini.

Bisa dilihat bagaimana penyesuaian para pendidik, stresnya orangtua yang mendampingi anak-anaknya belajar di rumah, dan tentunya bagaimana siswa kebingungan menghadapi tumpukan tugas yang aneh-aneh dari para pendidik yang sedang adaptasi. Tidak mudah menjalankan pembelajaran jarak jauh. Semua pihak saling bahu-membahu untuk menuju suksesnya pembelajran. Namun tidak dipungkiri ternyata banyak kendala yang menghambat lancarnya pembelajaran.

Pemahaman setiap siswa, keadaan orang tua serta situasi dalam rumah yang berbeda, membuat kualitas pembelajaran berbeda-beda. Namun, dengan adanya internet peserta didik dapat belajar untuk tahu, belajar untuk melakukan, belajar untuk menjadi sesuatu, dan belajar untuk hidup bersama dengan pendekatan yang sangat berbeda di masa pra internet di mana guru menjadi satu-satunya sumber belajar. Para pendidik cukup memfasilitasi bagaimana peserta didik dapat mencari tahu sumber belajar yang dapat dipercaya.

Semua pihak senantiasa menginginkan agar tujuan pendidikan dapat tercapai. Di tengah pandemi covid-19 ini, kerjasama antara orang tua dan guru sangat diperlukan agar tujuan pendidikan tetap dapat tercapai. Adanya sikap saling mempercayai, saling membantu dalam membimbing anak dan komunikasi antara orang tua dan guru, akan membuat anak merasa memiliki kebebasan berkreativitas guna pengembangan potensi dirinya, sehingga bisa meningkatkan kreativitas dan mencapai keberhasilan dalam belajar lebih bermakna dan bermanfaat. 


\section{Kesimpulan}

Pada masa pandemi coronavirus disease (Covid-19) ini, anak lebih dekat dengan keluarga terutama orang tua. Oleh karena itu, sangat urgen bagi orang tua menjalankan perananya mengorganisir kondisi belajar di keluarga, untuk menunjang prestasi belajar anak. Peran orang tua dalam mengoptimalkan prestasi belajar anak diantaranya yaitu sebagai pendidik, guru, motivator, supporter, fasilitator dan model (teladan). Adapun guru tetap berperan sebagai perencana (planner), pelaksana dan pengelola (organizer) dan penilai (evaluator). Guru dapat memberikan stimulasi kepada siswa dengan menyedikan tugas-tugas pembelajaran yang kaya (rich learning tasks) dan terancang dengan baik untuk meningkatkan perkembangan intelektual, emosional, spiritual, dan sosial.

Peran guru dan orang tua memang mendasar dalam mendukung proses anak belajar di rumah. Oleh karena itu, kerja sama antara orang tua dan guru dalam menjalankan peranannya sangat penting guna menyukseskan sistem pembelajaran secara daring (dalam jaringan) atau online agar menarik dan menyenangkan. Adanya sikap saling mempercayai, saling membantu dalam membimbing anak dan berkomunikasi antara orang tua dan guru, akan membuat anak merasa memiliki kebebasan berkreativitas guna pengembangan potensi dirinya, sehingga bisa meningkatkan kreativitas dan mencapai keberhasilan dalam belajar lebih bermakna dan bermanfaat.

\section{Daftar Referensi}

Bilfaqih, Yusuf dan M. Nur Qomarudin. 2015. Esensi Pengembangan Pembelajaran Daring. Yogyakarta: Deepublish.

Flewelling, Gary and William Higginson. 2003.Teaching with Rich Learning Tasks. Adelaide: The Australian Association of Mathematic Teacher. tp:ttp.

Hidayati, Wiji dan Sri Purnami.2008. Psikologi Perkembangan. Yogyakarta: Teras..

Isman. Mhd. 2016. Pembelajaran Moda Dalam Jaringan (Moda Daring). Universitas Muhammadiyah Sumatera Utara.

Nawawi, Hadari. 2011. Metode Penelitian Bidang Sosial.Yogyakarta: Gajah Mada Universitas Press.

Purwanto, Ngalim. Psikologi Pendidikan. Bandung: Remaja Rosdakarya 
Rima Trianingsih. Pengantar Praktik Mendidik Anak Usia Sekolah Dasar Article. IAI Ibrahimy Genteng Banyuwang. Vol. 3 No. 2. 2016. hal. 199-203.

Rusman. 2011. Model-Model Pembelajaran; Mengembangakan Profesionalisme Guru. Jakarta: PT Raja Grapindo Persada.

Soemarjan, Selo. 1962. Sosiologii Suatu Pengantar. Yogyakarta: Gajah Mada Press.

Sugiyono. 2011. Metode Penelitian Kombinasi. Bandung: Alfabeta.

Suyono dan Hariyanto. 2014. Belajar dan Pembelajaran Teori dan Konsep Dasar. Bandung: PT Remaja Rosdakarya.

Suyono dan Hariyanto. 2014. Belajar dan Pembelajaran Teori dan Konsep Dasar. Bandung: PT Remaja Rosdakarya.

Udin S. Winataputra. 2014. Teori Belajar dan Pembelajaran Modul. Universitas Terbuka. 2014.

Wahab, Rochmat. Peranan Orangtua dan Pendidik dalam Mengoptimalkan Potensi Anak Berbakatak Ademik. Dibahas dalam SEMINAR KEBERBAKATAN yang diselenggarakan oleh Dewan Eksekutif Mahasiswa Psikologi Universitas Diponegoro. Semarang pada 28 Mei 2005 di Semarang.

Yatimah. Durotu. 2017. Landasan Pendidikan. Jakarta: CV Alumgadan Mandir.

Anonim. Pengambilan sampel. Dalam "https://id.wikipedia.org/wiki/Sampel_(statistika)". diakses tanggal 19 April 2020 pukul 00.24 WIB.

Bayumie sukri. Dampak Korona Terhadap Pendidikan. dalam "https://intens.news/coronamakin-eksis-dunia-pendidikan-bermetamorfosis/”. diakses tanggal 19 April 202003.44 WIB

Cyranoski D (Maret 2020). "Misteri memperdalam sumber hewan coronavirus". Alam . 579 (7797): 18-19. Bibcode : 2020Natur.579 $\underline{18 C} \cdot \underline{\text { doi }}: \underline{10.1038 / d 41586-020-00548-w} \cdot \underline{\text { PMID }} \underline{32127703}$.diakses tanggal 19 April 2020. $01.00 \mathrm{WIB}$

Portal statistic. Pengambilan Sampel Purposive. dalam "http://www.portalstatistik.com/2014/02/teknik-pengambilan-sampel-dengan-metode.html”. diakses tanggal 19 April 2020 pukul 00.30 WIB. 